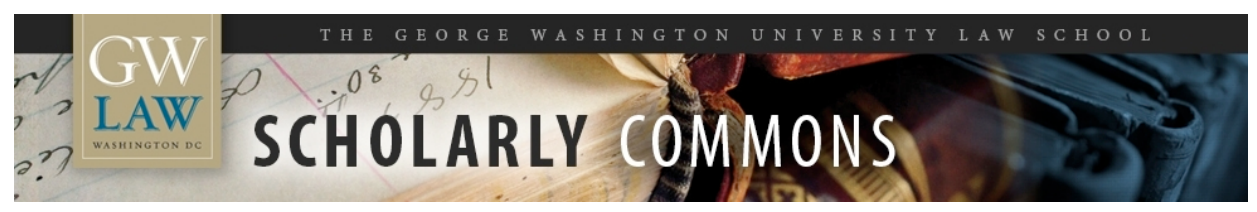

\title{
International Procurement Developments in 2018: The United States in International Procurement - Understanding a Pause in the Trump Administration's Protectionism
}

Christopher R. Yukins

George Washington University Law School, cyukins@law.gwu.edu

Follow this and additional works at: https://scholarship.law.gwu.edu/faculty_publications

Part of the Law Commons

\section{Recommended Citation}

Yukins, Christopher R., International Procurement Developments in 2018: The United States in International Procurement -- Understanding a Pause in the Trump Administration's Protectionism (2019). 2019 Gov't Contracts Year in Review Briefs 6 (Westlaw).; GWU Law School Public Law Research Paper No. 2019-51; GWU Legal Studies Research Paper No. 2019-51. Available at SSRN: https://ssrn.com/abstract=

This Article is brought to you for free and open access by the Faculty Scholarship at Scholarly Commons. It has been accepted for inclusion in GW Law Faculty Publications \& Other Works by an authorized administrator of Scholarly Commons. For more information, please contact spagel@law.gwu.edu. 
Reprinted from Thomson Reuters' Government Contracts Year In Review COVERING 2018 CONFEREnCE BRIEFs, with permission of Thomson Reuters. Copyright (@ 2019. Further use without the permission of Thomson Reuters is prohibited. For further information about this publication, please visit legal. thomsonreuters.com, or call 800.328.9352.

SESSION 2

INTERNATIONAL PROCUREMENT DEVELOPMENTS IN 2018-PART IV: THE UNITED STATES IN INTERNATIONAL PROCUREMENT: UNDERSTANDING A PAUSE IN THE TRUMP ADMINISTRATION'S PROTECTIONISM

\author{
Christopher R. Yukins \\ Professor of Government Procurement Law \\ George Washington University Law School, Washington, D.C.
}

As the Trump administration came of age in 2018, two distinct developments marked the United States' involvement in international procurement. First, to the surprise of many, and despite a wave of other U.S. protectionist measures aimed at strategic sectors such as steel and aluminum, the Trump administration did not press forward aggressively on its promised "Buy American" initiatives in procurement. Second, the Trump administration remained largely silent on an arguably protectionist initiative in the European Union, the European Defense Fund, which gained ground in one of the United States' most important defense markets abroad.

To address these two aspects of U.S. policy, this piece proceeds in five parts. Part I reviews the Trump administration's failure to move forward on the protectionist measures President Trump called for in the early days of his administration. In Part II, the piece discusses one of the possible causes for the Trump administration's reluctance to press for protectionism: a significant setback in the NAFTA/USMCA negotiations, which may narrow the administration's options going forward. Part III reviews other potential causes for the Trump administration's shift away from protectionism in procurement, including competing strategic concerns, new U.S. data on the relatively small threat posed by procurement from abroad, and data from Europe which confirms that U.S. exporters have much to lose were the European Union to take a retaliatory stance in European procurement markets. Finally, Part IV reviews the European Defense Fund, an initiative which surged forward in 2018 and which threatens to exclude U.S. defense companies from important opportunities in Europe, despite reciprocal defense procurement agreements which guarantee open markets in defense and -- again surprisingly -- with no loud objections from the Trump administration. Part V offers concluding remarks and a potential way forward.

\title{
I. BUY AMERICAN INITIATIVE NOW MUTED IN THE TRUMP ADMINISTRATION
}

At the start of the Trump administration, every indication was that the new president would unleash a suite of protectionist measures in procure- 
ment. Those could have included any number of measures, from higher "Buy American" price preferences, to tighter scrutiny of Buy American Act waivers, to protectionist measures in long-heralded legislation to rebuild public infrastructure in the United States. E.g., Christopher R. Yukins, The Trump Administration's Policy Options in International Procurement, 2017 Gov't Contracts Year in Rev. Br. 3. President Trump made a series of very public statements in favor of a new protectionism in federal procurement, and he issued Executive Order No. 13,788, 82 Fed. Reg. 18837 (Apr. 21, 2017), which called for data to be gathered for an administration study, to be submitted in November 2017, on whether new protections might be erected around the federal procurement market. Id. at 18838.

That Trump administration study on new "Buy American" measures never materialized, and the data on Buy American waivers rest largely unnoticed on the Federal Business Opportunities website, www.fbo.gov. (A GAO report from December 2018, discussed below, offered the somewhat flat explanation that, according to the White House, the data posted online -- which appear to be data gathered under the Executive Order but never used -- allow "vendors selling domestic products to more easily see how agencies acquire foreign goods pursuant to Buy American Act exceptions." GAO, Buy American Act: Actions Needed to Improve Exception and Waiver Reporting and Selected Agency Guidance, GAO-19-17, at 10 (Dec. 2018), https://www.gao.gov/assets/700/696086.pdf.)

The question, then, is why the lull -- why has the Trump administration paused in pressing for new "Buy American" protections in U.S. procurement? There are probably several good answers (beyond the political distractions dogging the Trump administration), including a surprising failure in the renegotiation of the North American Free Trade Agreement (NAFTA), a focus in negotiations on opening China and other major markets, and an emerging recognition that -- at least at this point -- sound data suggest that it would be a mistake for the United States to press for aggressive barriers to the U.S. procurement market. The discussion below will address each of these possible explanations in turn.

\section{THE USMCA SURPRISE: NO CANADA}

The first explanation for the Trump administration's quiescence may have been a significant -- and surprising -- setback in the proposed replacement for NAFTA, the United States-Mexico-Canada Agreement (USMCA). ${ }^{1}$ In an unexpected turn, Canada ultimately refused to join Chapter 13 of the USMCA, which addresses procurement. See, e.g., Christopher R. Yukins, Feature Comment: The U.S-Mexico-Canada Agreement (USMCA): Some Surprising Outcomes in Procurement, 60 Gov. Contr. II 308 (Oct. 10, 2018). As Jean Grier noted in her blog, the "USMCA is the first U.S. free trade agreement (FTA) to not include procurement commitments for all parties." Jean Heilman Grier, USMCA -- Modernized NAFTA: Procurement (Oct. 5, 2018), https:// trade.djaghe.com/?p=5174.

The Canadian government's refusal to join the procurement chapter may have stemmed from a very aggressive posture the United States took earlier in the negotiations. The U.S. negotiators reportedly put forward a concept of strict "reciprocity" -- that the U.S. procurement market would be opened only to the extent that a trading partner could offer the same dollar-for-dollar access. See, e.g., Jean Helman Grier, NAFTA Procurement: Capping Access? (Oct. 4, 2017), https://trade.djaghe.com/?p=4351. Thus (in theory) the Canadian government, with perhaps roughly one tenth of the annual procurement of 
the U.S. government, see, e.g., Government of Canada, 2016 Purchasing Activity Report, https://www.canada.ca/en/treasury-board-secretariat/corporate/ reports/contracting-data/2016-purchasing-activity-report.html,would gain access to only one-tenth of the U.S. federal market.

This "strict reciprocity" would probably have been administratively unworkable; over any given year, it could have meant access swinging open and shut to different trading partners at different times and at different levels in a Rube Goldberg-type scheme, badly disrupting cross-border trade and U.S. agencies' ability to access best-value solutions abroad. See, e.g., Jean Heilman Grier, NAFTA Procurement: Capping Access, supra. Strict reciprocity also could have shredded the traditional principles of comity and open markets that have informed U.S. trade policy in procurement since World War II -- the same principles that led to the WTO's plurilateral Government Procurement Agreement, which now includes most industrialized nations. See, e.g., Christopher R. Yukins \& Steven L. Schooner, Incrementalism: Eroding the Impediments to a Global Public Procurement Market, 38 Geo. J. Int'l L. 529 (2007), http://papers.ssrn.com/sol3/papers.cfm?abstract id=1002446.

Unsurprisingly, the Canadian negotiators reacted very negatively to "strict reciprocity," see, e.g., Jasso, Canada's Lead NAFTA Negotiator Criticizes U.S. Proposal as Freeland Heads to Washington, Globe \& Mail, Feb. 13, 2018, and Canada ultimately simply refused to join the USMCA's procurement chapter. As a result, if the USMCA comes into effect, replacing NAFTA (an open question, given shifting politics in the United States), procurement trade between Canada and the United States instead will be governed by the WTO Government Procurement Agreement, which Canada and the United States joined long ago. Compared to current access under NAFTA, the GPA affords U.S. vendors slightly narrower access to Canadian procurement markets. See Jean Heilman Grier, USMCA, supra ("While U.S. suppliers will continue to have access to the extensive procurement that Canada covers under the WTO Government Procurement Agreement (GPA), they will lose some benefits accorded under the NAFTA, specifically relating to thresholds and coverage of services."). In sum, despite President Trump's claim that the USMCA was the "largest trade deal ever," in procurement the agreement may have left U.S. businesses in a weaker place -- and it left out an entire country, Canada.

The scuffle over "strict reciprocity" under the USMCA had two collateral effects, both largely unforeseen.

First, the Canadian government's refusal to join the USMCA procurement chapter suddenly made it more difficult for the United States to leave the WTO Government Procurement Agreement, despite broad public speculation that the United States would prefer to abandon the plurilateral GPA in favor of bilateral arrangements in which the United States would hold more negotiating leverage. As representatives of the U.S. automotive industry noted in their comments on the USMCA, if "the Administration were to withdraw the U.S. from the WTO/GPA, which is not inconceivable, U.S. exporters would have no access to the Canadian government market." Industry Trade Advisory Committee on Automotive Equipment and Capital Goods (ITAC-2), USMCA Report, Addendum, at 2 (Oct. 24, 2018), https://ustr.gov/sites/default/files/files/agreements/FTA/AdvisoryCommitteeReports/ITAC_2_REPORT-Automotive_Equipment and Capital Goods Addendum.pdf. Thus, by retreating to rely solely on the GPA for U.S.-Canadian procurement access, the Canadian government significantly raised the stakes for the United States, were it to abandon the GPA. 
The second effect of the fight over "strict reciprocity" related to Mexico, and may spell the end of "strict reciprocity" as a negotiating tool. A paper published by the U.S. Chamber of Commerce during the USMCA negotiations reported that because in practice Mexican firms seldom exercise their right to access U.S. public procurement under NAFTA, limiting procurement access across the U.S.-Mexico border in a rigidly reciprocal manner under USMCA could, in practice, sharply reduce U.S. firms' existing (and much broader) access to Mexican public markets. See, e.g., Murphy, U.S. Chamber of Commerce, Gutting NAFTA's Procurement Rules Could Cost Americans Billions (Jan. 24, 2018), https://www.uschamber.com/series/modernizing-nafta/guttingnafta-s-procurement-rules-could-cost-americans-billions. Possibly because of this insight that "strict reciprocity" could in fact hurt U.S. exporters, the final text of the USMCA did not provide for strict reciprocity in procurement trade between the United States and Mexico. It is possible, too, that because the USMCA negotiations laid bare the potentially adverse effects of "strict reciprocity," the idea has now died a quiet death.

\section{SHIFTING PERSPECTIVES ON PROTECTIONISM}

There may be other, less immediately tangible reasons for the lull in the Trump administration's protectionism in procurement.

The Trump administration's policy makers working in procurement appear to have pivoted to focus on securing the U.S. industrial base, and on ensuring security of supply during times of conflict. A recent report to the Defense Department highlighted the need to ensure security of supply, not necessarily by excluding all foreign vendors, but instead by prudent assessments of risk in the supply chain. See Interagency Task Force in Fulfillment of Executive Order 13806, Assessing and Strengthening the Manufacturing and Defense Industrial Base and Supply Chain Resiliency of the United States (Sept. 2018). Recent interim regulations issued by the Committee on Foreign Investment in the United States (CFIUS) (reviewed in John Barker's accompanying piece) focus on ensuring that foreign investors cannot gain access, through a procurement or otherwise, to sensitive U.S. technologies. Finally, Section 885 of the National Defense Authorization Act for Fiscal Year 2019, Public Law No. 115-232, called for new regulations to restrict foreign access to U.S. technologies through procurement.

Moreover, the Administration's broader trade policy is clearly aimed first at opening major markets such as China's, for example. As the Administration's focus shifts to opening markets, the Administration may be reluctant to rely too heavily on measures such as the Buy American Act, which can readily close a U.S. market but may be too blunt a weapon to open target markets abroad, at least in the near term. While the Buy American Act and other protectionist measures are at the heart of U.S. trade strategy under the Trade Agreements Act -- under the Act, the United States waives those protectionist measures for countries that agree to open their own procurement markets -- in the near term (the timeline for a Trump administration focused on reelection) new protectionist measures in procurement may not do enough, quickly enough. New barriers to trade in procurement, such as sharply increased price preferences for U.S. vendors, may be too slow to force open specific foreign markets (such as the strategic Chinese market) or to protect politically sensitive U.S. sectors (such as manufacturing).

The data available to the Trump administration's policy makers also may make protectionism in procurement seem a poor means of countering 
a mammoth U.S. trade deficit. A recent study by the Government Accountability Office, noted above, concluded that only $\$ 7.8$ billion, or less than $2 \%$ of the approximately $\$ 500$ billion in federal procurement each year, were attributable to foreign end products. (The study did not attempt to estimate the value of foreign-origin components or services.)

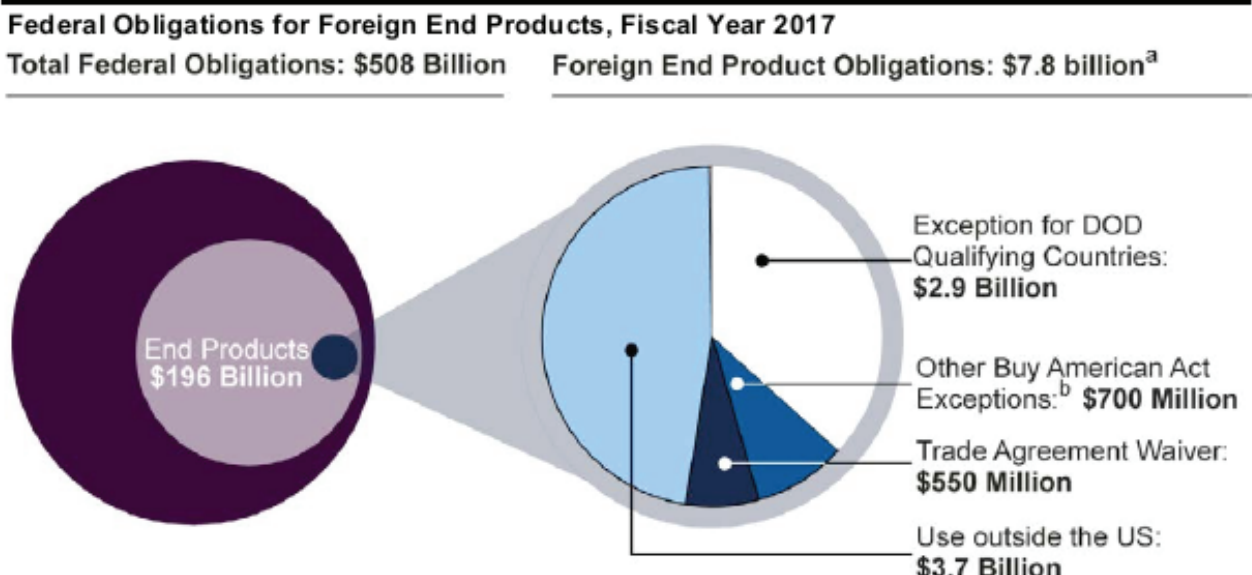

The GAO study, summarized in the chart above, found that of $\$ 508$ billion in procurement (much of which were in services), $\$ 196$ billion were in end products that could be subject to the Buy American Act. Of those, only $\$ 7.8$ billion (4\% of all end products purchased, and $1.5 \%$ of all procurement in FY2017) were end products of foreign origin. (The GAO report also found that these data were generally consistent with prior years' data.) Of the $\$ 7.8$ billion in foreign end products, roughly half were for use outside the United States (and thus exempt from the Buy American Act), approximately a third were from "qualifying countries" (i.e., subject to reciprocal defense procurement agreements, discussed below), and only $\$ 550$ million (roughly .1\% of all procurement) were admitted under trade agreements. In practical terms, this meant:

- $\quad$ Overall, foreign-source supplies are only a very small part of U.S. procurement, and eliminating them entirely -- by barring federal agencies from using any foreign goods in the United States, for example -- would cover only roughly $\$ 4$ billion in goods and thus would have no discernible impact on the overall U.S. trade deficit (which in 2017 was $\$ 566$ billion), and could compromise U.S. agencies' abilities to achieve their missions when foreign goods provide the best value.

- $\quad$ Dismantling free trade agreements, such as the GPA, likely would have only a tiny effect in increasing federal agencies' purchases of U.S.-made goods.

- $\quad$ Reciprocal defense procurement agreements -- as noted below, a cornerstone to open defense trade -- played a much more important role than traditional free trade agreements in opening U.S. procurement markets.

Notably the GAO study did not attempt to assess the impact that new protectionist measures might have on U.S. exporters' access to foreign procurement markets. The GAO study showed, for example, that European nations are leading sources of the foreign end products purchased by federal agencies, 
$i d$. at 41 , but did not assess what impact new protectionist measures might have on U.S. exporters, were (for example) the European Union to retaliate against U.S. protectionism.

Data published by the European Commission on larger, reported awards suggest that U.S. exporters have very favorable access to European procurement markets, both in direct sales and in indirect sales (through European entities). See European Commission, Measurement of Impact of Cross-Border Penetration in Public Procurement (Feb. 2017), https://publications.europa.eu/ en/publication-detail/-/publication/5c148423-39e2-11e7-a08e-01aa75ed71a1/ language-en. The European Commission's data show that the United States is consistently the leading non-EU exporter to the European Union's procurement markets, in both direct and indirect procurement sales, and in both numbers of contract actions and value. Id. at $41 \& 43$. The Commission's data, id. at 48 , also show that U.S. companies win $3.8 \%$ of all the direct awards studied (a figure which compares favorably to all foreign end products awards in the U.S. system (see above)), and fully $21.8 \%$ of all indirect awards (i.e., awards through European subsidiaries), $i d$. at 49 . While the finer points of the European Commission's data have been contested by U.S. officials, the data at least indicate that U.S. companies have a strong foothold in European public procurement markets -- a market position that could be imperiled were U.S. protectionism to trigger European retaliation.

There is another type of economic analysis just over the horizon: econometric analyses of the broader, economy-wide impacts of protectionist measures. These econometric studies do not yet shape the public debate, but are likely to become much more relevant to policy assessments. The European Commission is spending millions of Euros constructing a database which will allow policy makers to analyze, in stark empirical terms, the direct and indirect costs of new barriers to procurement trade. See generally Lucian Cernat \& Zornitsa KutlinaDimitrova, International Public Procurement: From Scant Facts to Hard Data, DG TRADE Chief Economist Notes 2015-1 (Directorate General for Trade, European Commission), https://ideas.repec.org/p/ris/dgtcen/2015_001.html. Many of the costs of protectionism, such as efficient supply chains disrupted by inefficient preferences, traditionally have been too obscure to capture or measure; the European Commission's initiative aims to remedy that. The Commission's initiative builds on an earlier study at Victoria University (Australia), which drew on econometric data regularly used by U.S. agencies to conclude that the "Buy America" preferences in U.S. law (preferences which go, for example, to federally funded transportation procurement) cost hundreds of thousands of lost U.S. jobs. See Peter B. Dixon, Maureen T. Rimmer \& Robert G. Waschik, Macro, Industry and Regional Effects of Buy America(n) Programs: USAGE Simulations, Victoria University, Melbourne Centre of Policy Studies Working Paper No. G-271 (April 2017), http://www.copsmodels.com/ftp/workpapr/g-271. pdf. These types of probing econometric studies may well reshape how policy makers think about protectionism in procurement for decades to come.

All of the foregoing help explain why the Trump administration has seemed to pivot in its approach to protectionism in procurement, to step back from an early emphasis on "Buy American" measures. What they do not explain, however, is why the Trump administration has remained largely acquiescent in an important new initiative in the European Union, the European Defense Fund, which threatens to undermine U.S. market dominance in defense and appears to contradict longstanding reciprocal agreements to open defense markets on either side of the Atlantic. 


\section{EUROPEAN DEFENSE FUND MOVES FORWARD, WITHOUT REAL RESISTANCE}

The European Defense Fund, originally launched in 2016, advanced markedly in 2018, and in December 2018 the European Parliament approved billions of Euros in new funding. See European Parliament Votes to Give EUR 13 Billion Subsidy to Arms Companies via European Defence Fund, Targeted News Serv., Dec. 13, 2018 (available on Westlaw). The European Development Fund would provide support for joint efforts among European defense firms to develop and produce defense materiel. Under a European regulation put forth in 2018, no support would be available for firms based, or run by those, outside the European Union. See Christopher R. Yukins, Feature Comment: European Commission Proposes Expanding The European Defence Fund-A Major Potential Barrier To Transatlantic Defense Procurement, 60 Gov. Contr. II 196 (2018).

The European Defense Fund thus appears to contradict the U.S. Defense Department's many reciprocal defense procurement agreements with its European allies. See Department of Defense, Defense Procurement and Acquisition Policy, Reciprocal Defense Procurement and Acquisition Policy Memoranda of Understanding, https: / / www.acq.osd.mil / dpap/cpic/ic/reciprocal_procurement_memoranda_of_understanding.html; see DFARS DFARS 226.872. Those European nations, among other allies known as "qualifying" countries, generally enjoy free access to U.S. defense procurements, including for research and development, and in return U.S. defense firms are to enjoy reciprocal access to the allied countries' defense markets. See, e.g., Christopher Yukins \& Daniel Ramish, Feature Comment, Section 809 and 'e-Portal' Proposals, By Cutting Bid Protests In Federal Procurement, Could Breach International Agreements And Raise New Risks Of Corruption," 60 Gov. Cont. II 138 (May 2, 2018) (discussing agreements). Those reciprocal agreements to open defense markets have helped the United States become a leading arms provider in Europe, and have helped secure close cooperation in defense procurement between the United States and its European allies.

In light of that longstanding tradition of open and cooperative defense procurement across the Atlantic, the European Defense Fund seems an anomaly -- an oddly protectionist gambit by the European Union despite subdued concerns from the U.S. defense community (and others) that the Defense Fund violates standing requirements for open procurement. See, e.g., European Defence Fund Could Be Breaching European Treaties, Legal Opinion Says, EurActiv, Dec. 14, 2018 ("None of our initiatives, including the [European Defense Fund], change the procurement rules in defence in Europe," Jorge Domecq, chief executive of the European Defence Agency, told a defence industry summit in Brussels in early December. "We hear a lot about this from our American allies, for example, but it is fake news.") (available on Westlaw); Creating European Defence Fund Would Breach EU Treaty \& Further Undermine Irish Neutrality, 2018 WLNR 38761983 (Sinn Fein Member of the European Parliament Matt Carthy "has condemned the vote of the European Parliament this week in favour of establishing a European Defence Fund (EDF), while welcoming the publication of a legal opinion which finds that the creation of an EDF would be in breach of the Treaty on the Functioning of the European Union.") (available on Westlaw). The progress made by the European Defense Fund, and the Trump administration's failure to complain, may be due to a number of factors. 
The first and most obvious is the desire of many European nations, prodded by President Trump, to spend more on their own defense. See, e.g., Michael Barnier, Europe's Future Is Up To Us, Project Syndicate, Jan. 4, 2019; David M. Herszenhorn, How to Improve Europe's Military Defense, POLITICO, Dec. 7, 2018, https://www.politico.eu/article/working-group-berlin-how-to-improveeuropes-military-defense/. The European Defense Fund is intended to help integrate a very fragmented European defense industry, because the Fund will provide development funding only if the new efforts involve multiple Member States. While this new funding may address President Trump's complaints that the European states do not spend enough on defense, limiting the new funding to European firms seems to contradict the reciprocal defense agreements described above. That, in turn, may reflect a new assertiveness in European policy, an overt desire to challenge the "bullying" that Europeans perceive from the Trump administration in foreign trade (and defense).E.g., European Parliament, Directorate-General for External Policies -- Policy Department, Consequences of US Trade Policy on EU-US Trade relations and the Global Trading System (2018), http://www.europarl.europa.eu/RegData/ etudes/STUD/2018/603882/EXPO STU(2018)603882 EN.pdf.

But while all of that explains the Europeans' actions, none of it explains why the Trump administration has offered only muted concerns about the European Defense Fund. See, e.g., Steven Erlanger, U.S. Revives Concerns About European Defense Plans, Rattling NATO Allies, N.Y Times, Feb. 18, 2018. Although that acquiescence from Washington may be due to U.S. willingness to overlook European protectionism in order to encourage enhanced European defense spending, there may be a more fundamental obstacle to engagement. While the Trump administration has been very publicly engaged in opening foreign markets and protecting domestic industries, it has largely overlooked the third, diplomatic element of foreign trade: to use trade as leverage for stronger, more secure relationships between nations. It is that third aspect of foreign trade policy -- comity and cooperation -- that is directly threatened by the European Defense Fund's overtly exclusionary structure. Having largely set aside comity and cooperation in foreign trade, however, the Trump administration may simply lack the voice to complain pointedly about the emerging European Defense Fund.

\section{v. CONCLUSION}

This past year was clearly one of flux, and the coming year may see further changes. President Trump may be swept up in political and legal challenges, which could derail his foreign trade initiatives; at the same time, though, those challenges may prompt his administration to redouble its protectionist initiatives, and to include procurement markets in those efforts. While those next steps are unclear, what is clear is that there are sound historical and empirical reasons to steer away from protectionism in procurement, and to reclaim the comity and cooperation that helped shape the world economic order in the decades after World War II -- an economic order that, until very recently, included progressively opening markets in procurement. 